Original article

\title{
Uzaktan Eğitimin Değerlendirmeye Yansımaları: Çevrim İçi Sınavlar mı Sınıf İçi Sınavlar mı?
}

\section{Distance Education's Impact on Assessment: Online Exams or Classroom Exams?}

\author{
Meltem Acar Güvendir (1) a, * \& Yeşim Özer Özkan (1) b \\ ${ }^{a}$ Department of Educational Sciences, Faculty of Education, Trakya University, Edirne, Turkey \\ ${ }^{\mathrm{b}}$ Department of Educational Sciences, Gaziantep Faculty of Education, Gaziantep University, Gaziantep, Turkey
}

\begin{abstract}
Özet
Araştırmanın amacı öğretmen adaylarının çevrim içi sınavlarla sınıf içi uygulanan sınavları, geçerlik, güçlük, kaygı durumu, objektiflik, kullanışlılık, notların duyurulması ve verilen dönütler, sınıf ortamı ve sınav öncesi ders çalışma süresi açılarından karşılaştırmalı olarak değerlendirmelerini ortaya koyabilmektir. Çalışma grubunu Trakya Üniversitesi’nde, 2020-2021 güz döneminde sınıf öğretmenliği anabilim dalı dördüncü sınıfında öğrenim gören 8 öğretmen adayı oluşturmuştur. Öğretmen adaylarının 2'si erkek, 6'sı kadındır. Verilerin toplanması sürecinde sekiz görüşme sorusu odak grup görüşmesi tekniği ile çalışma grubuna yöneltilmiştir. Çalışmanın kavramsal yapısı ve analizine temel oluşturacak temalar önceden belirlendiği için, betimsel analiz yöntemi uygulanmıştır. Sonuç itibariyle, öğretmen adaylarına göre çevrim içi sınavlar sınıf içi sınavlara göre zamandan ve mekândan bağımsız olarak yapılabildiği için daha kullanışlı olsa da kopya durumuna çok açık olması, tek tip soru türünün kullanılmasından ve bilenle bilmeyen öğrencileri ayırt etme açısından geçerli bir sınav değildir. Ayrıca öğretmen adayları, çevrim içi sınavlarda yaşanabilecek olası teknik problemlerden (elektrik ve internet kesintisi) dolayı çok fazla kaygı yaşadıklarını dile getirmişlerdir. Çevrim içi sınavları sınıf içi sınavlarla karşılaştırdıklarında, sınav öncesi sınıf içi sınavlara göre daha az ders çalıştıklarını belirtmişlerdir. Özetle, çevrim içi öğrenme ortamına ve bu doğrultuda çevrim içi sınav sistemine zorunlu ve beklenmedik bir durumda geçilen bu süreçte, yaşanılan problemler, sınavın özellikle geçerlik, güvenirlik ve kullanışlılık özelliklerine yöneliktir. Bu anlamda çevrim içi sınavlar her ne kadar kullanışlı gibi görünse de bu sınavların geçerlik ve güvenirliği tartışıımaktadır.
\end{abstract}

Anahtar Kelimeler: Çevrim içi sınavlar, sınıf içi sınavlar, geçerlik, güvenirlik, kullanışlıık.

\begin{abstract}
The purpose of this study is to compare online and classroom tests in terms of validity, difficulty, anxiety, objectivity, and usefulness, as well as the process of announcing grades and providing feedback, as well as the classroom setting and study time prior to the exam. The study group comprised of eight teacher candidates in their fourth year in the classroom teaching department at Trakya University during the fall semester of 2020-2021. Two of the teaching applicants are male, while the remaining six are female. Using the focus group interview methodology, eight interview questions were directed at the study group during the data gathering phase. Due to the fact that the study's conceptual structure and the themes that will form the basis of its analysis were established in advance, the descriptive analysis approach was used. As a result, while online exams, according to pre-service
\end{abstract}

\footnotetext{
* Corresponding author:

Meltem Acar Güvendir, Department of Educational Sciences, Faculty of Education, Trakya University, Edirne, Turkey. Email: meltemacar@trakya.edu.tr
} 
teachers, are more useful than in-class exams because they can be completed independently of time and place, they are not a valid means of distinguishing students who know from those who do not know due to the exam's use of a single type of question, which is highly susceptible to cheating. Additionally, pre-service instructors expressed high levels of anxiety about the possibility of technological difficulties (power and internet outages) during online assessments. When students compared online exams to in-class tests, they claimed that they studied less for the online examinations than they did for the classroom tests. In summary, the difficulties encountered throughout this procedure, in which the online learning environment and online exam system were forced into an unforeseen position, are mostly connected to the exam's validity, dependability, and usefulness. In this regard, though online exams appear to be beneficial, their validity and trustworthiness are contested.

Keywords: Online exam, classroom exam, validity, reliability, and usability.

Received: 11 June $2021 \quad$ * Accepted: 22 June $2021 \quad$ * DOI: https://doi.org/10.29329/dmer.2021.285.2

\section{GíRiş}

Bütün dünyada Kovid-19 sosyal, kültürel, ekonomik ve politik yaşamı derinden etkilemiş ve yeniden şekillendirmiştir. Salgının en çok etkilediği kurumların başında eğitim gelmektedir. Salgın önlemleri kapsamında, üniversitelerde 16 Mart 2020 tarihinden itibaren önce eğitime ara verilmiş, daha sonra uzaktan eğitim yoluyla eğitim öğretimin devam etmesi sağlanmıştır. Üniversitelerde bir gecede yüz yüze yürütülen eğitim, sanal ortama taşınmak zorunda kalınmıştır. Pandemiyle birlikte ani bir kararla bir zorunluluk olarak uzaktan eğitime geçilmesi, sistem içindeki herkesin bu geçişe hazırlıksız yakalanmasına neden olmuştur. Hodges, Moore, Lockee, Trust, ve Bond (2020) bu durumu, "acil durum uzaktan öğretimi” olarak nitelendirmişler ve planlı yapılan çevrimiçi öğrenmelerden ayrı tutulması gerektiğini vurgulamışlardır. Bu tanımlamanın yapılma nedeni, çevrimiçi öğrenme ortamında planlanan eğitimler önceden planlanmış çevrimiçi değerlendirme yöntemleriyle en baştan uzak olacak şekilde tasarlanmıştır. Kovid-19 gibi bir kriz veya felakete yanıt olarak düzenlenen çevrimiçi öğrenme ortamları bunlardan çok farklıdır ve acil durum uzaktan öğretimi olarak planlanmaktadır. Bu durumun bir sonucu olarak eğitim öğretim içeriğinin çevrimiçi hazırlanmasından değerlendirme basamağına kadar her aşamanın uzaktan eğitimle planlanmasını gerekli kılmıştır. Teorik derslerin işlenmesiyle ilgili sorunların bir şekilde aşılması mümkün olsa da ölçme ve değerlendirmenin nasıl yapılacağının belirlenmesi çok kolay görünmemektedir (Sarı, 2020).

Yüz yüze eğitimde de uzaktan eğitimde de eğitim öğretimin niteliğinin tartışılmasından çok, değerlendirmenin dolayısıyla sınavların daha çok tartışıldığı söylenebilir. Sistemin tamamlayıcı bir halkası, bir alt öğesi, geliştirici bir geri bildirim mekanizması olan değerlendirmenin, Türkiye'de daha fazlasını ifade ettiği söylenebilir. Eğitim sisteminin bir alt öğesi olması gerekirken sınavlara yüklenen anlam dolayısıyla Türkiye'de değerlendirme, eğitim sistemini yönlendiren, sistemin üstünde, tamamlayıcı yerine belirleyici bir öğe olarak görülmektedir (Özer Özkan ve Turan, 2021). Eğitimin dar 
boğazı olarak nitelendirilen ölçme ve değerlendirme uzaktan eğitimle birlikte daha çok tartış1lır hale gelmiştir. Ölçme ve değerlendirme faaliyetleri kapsamında uzaktan eğitimde öğrencileri izlemeye dönük yapılan anlık geri bildirimlerin nasıl verilebileceğinden, dönem sonunda öğrencilere değer biçme amacıyla yapılacak sınav veya ödevlerin nasıl olması gerektiği ve sınav güvenliğinin nasıl sağlanacağı üzerinde çok düşünülen konular olmuştur. Çünkü bir anlamda değerlendirme bilen bilmeyen öğrencilerin belirlenmesi, öğrenciye performansı hakkında somut bir geri bildirim verildiği aşama olması, üzerine yüklenen anlamı arttırmaktadır. Başarılı öğrencinin bir derse motive olduğu veya hayal kırıklığına uğradığı süreç, genelde değerlendirme basamă̆ıdır. Öğrenci, yapılan değerlendirmenin adil, şeffaf, hesap verilebilir, güvenilir, geçerli ve kullanışlı olduğuna inanmıyorsa o derse olan motivasyonunu da kaybetmektedir. Bu nedenle eğitimin dar boğazı ölçme ve değerlendirme ve bunun belirlendiği araçlar olan sınavlar olarak görülmektedir.

Yüz yüze eğitimde sinavlar genellikle kâğıt kalem testi olarak uygulanmaktaydı. Uzaktan eğitimde ise çevrim içi sınav ya da ödev şeklinde gerçekleştirilmiştir. Çevrimiçi sınavlarda öğrenciler bir sistem üzerinden kendilerine yöneltilen soruları yanıtlamaktadırlar. Sistemsel bir önlem alınmadığında ya da canlı gözetmenler kullanılmadığında gözetimsiz gerçekleştirilmektedir. Gözetimsiz gerçekleştirilen sınavların güvenirlik ve geçerliği, çokça tartışılan bir konu olmaktadır. Çünkü sınavların güvenilir ve geçerli olması yapılacak değerlendirmenin adilliğinin belirleyicisi olacaktır. Dolayısıyla sınavların güvenirlik ve geçerliğini tehlikeye atacak bazı durumlar (kopya, ipucu, sınava giren kişinin gerçek kişi olup olmadığının kontrol edilememesi vb.) çevrimiçi sınavlarla birlikte daha çok gündeme gelmiştir. Sınavların yüz yüze yapılamaması sınav güvenliğinin nasıl sağlanacağına ilişkin tartışmaları gündeme getirmiştir (Karahocagil, Çiçek ve Güneş, 2021). Üniversitelerin kullanmış oldukları bazı yazılımlar sınav güvenliğini arttırmaya yönelik bir takım önlemleri (ekran paylaşımını engelleme, soruların ardışık gelmesini sağlama, tek giriş hakkı tanıma vb.) içermektedir. Yazılımların sağladığı güvenlik önlemlerinin yanı sıra bazı üniversiteler sınavlarında gözetmen kullanarak sınavlarını gözetimli olarak gerçekleştirmiştir. Güvenli ve güvenirliği yüksek bir sınav sunmak ve kopya çekme olgusunu azaltmak için önceden düzenlemelere ve iyi bir hazırlığa ihtiyacı vardır. Ayrıca sınavlarda kopya çekme oranlarını azaltabilecek yüksek maliyetli materyalin sürekli ve teknolojik olarak geliştirilmesi gerekmektedir (Al-Shalout, Rasmi, ve Hassan,2021). Bu materyallerin sağlanamamasından dolayı sınavların büyük çoğunluğu bu önlemler alınmadan gerçekleştirilmektedir.

Atılgan vd.'nin (2020) belirttiği gibi, öğrenciler uzaktan eğitimde yapılan ölçme ve değerlendirmelerde en çok sınav güvenliği, teknik aksaklıklar ve ortamla ilgili problemlerin olduğunu dile getirmişlerdir. Sınav güvenliğinin sağlanamamasının bir sonucu olarak öğrencilerin kopya çekme girişimleri uzaktan eğitimle birlikte oldukça artmıştır. Rossiter (2020), kopyanın üniversiteler için beklenmedik bir KOVID-19 yan etkisi haline geldiğini bir önceki öğretim yılına kıyasla akademik sahtekârlıkta yüzde 38'lik bir artışla, küresel olarak kopya davranışında bir artışın olduğunu 
vurgulamıştır. Uzaktan eğitimle birlikte daha fazla eleştirilerin odağı olan sınavların tartışılması, bu sınavlardan elde edilecek verilerin sonuçlarının güvenirliğinden geçerliğine kadar birçok temel özelliğin sorgulanmasını gündeme getirmiştir.

Bir ölçme aracında bulunması gereken üç temel psikometrik özellik olan güvenirlik, geçerlik ve kullanışl11ık bakımından çevrimiçi sınavları sınıf içi uygulanan sınavlarla karşılaştırmak bir gereklilik olarak görülmüştür. Buradan hareketle araştırmanın amacı, öğretmen adaylarının çevrim içi sınavlarla sınıf içi uygulanan sınavları, geçerlik, güçlük, kaygı durumu, objektiflik, kullanışlılık, notların duyurulması ve verilen dönütler, sınıf ortamı ve sınav öncesi ders çalışma süresi açılarından karşılaştırmalı olarak değerlendirmelerini ortaya koyabilmektir.

\section{YÖNTEM}

\section{Çalışma grubu}

Çalışma grubunu Trakya Üniversitesi’nde, 2020-2021 güz döneminde sınıf öğretmenliği anabilim dalı dördüncü sınıfında öğrenim gören 8 öğretmen adayı oluşturmuştur. Öğretmen adaylarının 2'si erkek, 6'sı kadındır. Çalışma için dördüncü sınıf öğrencilerinin seçilmesinin sebebi, bu öğrencilerin üç yıla yakın bir süre üniversitede sınıf içi sınavlara, bir yıla yakın bir süre de çevrim içi sınavlara katılmış olmalarıdır.

\section{Veri Toplama Aracı}

Verilerin elde edilmesinde, çevrim içi sınavlarla ilgili alanyazın taranmış ve çevrim içi sınavların farklı yönlerini ortaya koyabilmeyi amaçlayan on görüşme sorusu hazırlanmıştır. Bu taslak 10 görüşme sorusunun uygunluğu açısından Bilgisayar ve Öğretim Teknolojileri Öğretmenliği alanından bir öğretim üyesi ve Eğitimde Ölçme ve Değerlendirme alanından iki öğretim üyesinin görüşü alınmıştır. Özellikle Bilgisayar ve Öğretim Teknolojileri Öğretmenliği alanındaki öğretim üyesi, çevrim içi sınavların tüm yönlerini ortaya koymada önemli dönütlerde bulunmuştur. Bunun yanı sıra Eğitimde Ölçme ve Değerlendirme alanındaki öğretim üyelerinin ise bazı sorularda ifadelerin değiştirilmesi ya da eklenmesi ve bazı soruların çıkarılması gibi önerileri olmuştur. Yapılan öneriler doğrultusunda sorulara son şekli verilmiştir. Sonuç olarak sekiz görüşme sorusu odak grup görüşmesi için hazır hale getirilmiştir. Sorular aşağıda belirtildiği gibidir.

1. Çevrim içi sınavları, sınıf içi sınavlarla karşılaştırdığınızda geçerlik açısından nasıl değerlendirirsiniz?

2. Çevrim içi sınavları, sınıf içi sınavlarla karşılaştırdığınızda güçlük açısından nasıl değerlendirirsiniz?

3. Çevrim içi sınavları, sınıf içi sınavlarla karşılaştırdığınızda yaşadığınız kaygı açısından nasıl değerlendirirsiniz? 
4. Çevrim içi sınavları, sınıf içi sınavlarla karşılaştırdığınızda objektiflik açısından nasıl değerlendirirsiniz?

5. Çevrim içi sınavları, sınıf içi sınavlarla karşılaştırdığınızda kullanışlılık açısından nasıl değerlendirirsiniz?

6. Çevrim içi sınavları, sınıf içi sınavlarla karşılaştırdığınızda notların duyurulması ve verilen dönütler açısından nasıl değerlendirirsiniz?

7. Çevrim içi sınavları, sınıf içi sınavlarla karşılaş̧ırdığınızda sınav ortamı açısından nasıl değerlendirirsiniz?

8. Çevrim içi sınavları, sınıf içi sınavlarla karşılaştırdığınızda sınav öncesi ders çalışma süresi açısından nasıl değerlendirirsiniz?

\section{Veri Toplama Süreci}

Çalışmanın verileri odak grup görüşmesi ile toplanmıştır. Görüşmeler, 2020-2021 öğretim y1lı güz döneminde pandemi süreci devam ettiğinden Microsoft Teams uygulaması üzerinden yapılmıştır. Sekiz öğrenci ile yapılan odak grup görüşmesi 57 dakika 25 saniye sürmüştür. Görüşme öncesi öğretmen adaylarına çalışma ile ilgili bilgi verilmiş ve rızaları doğrultusunda görüşme yapılmıştır. Görüşme Microsoft Teams Stream uygulamasına kaydedilmiş ve ardından bu uygulama üzerinden indirilen görüşme kaydının çözümlenmesi yapılarak, görüşme içeriği yazılı olarak elde edilmiştir.

\section{Verilerin Çözümlenmesi}

Çalışmanın kavramsal yapısı ve analizine temel oluşturacak temalar önceden belirlendiği için, betimsel analiz yöntemi (Yıldırım ve Şimşek, 2005: 223) uygulanmıştır. Öncelikle sekiz görüşme sorusu temel alınarak sekiz ayrı tema oluşturulmuştur. Bu temalar: geçerlik; güçlük derecesi; kaygı durumu; objektiflik; kullanışl11ık; dönütlerin verilmesi; sınav ortamı; sınav öncesi çalışma süresi şeklindedir.

Verilerin iç geçerliğini arttırmak için görüşme kaydı iki araştırmacı tarafından ayrı ayrı analiz edilmiştir. Yapılan analizler karşılaştırılarak ortak ya da farklı bir sonucun elde edilip edilmediği tartışılmış ve son bulgular ortaya çıkarılmıştır. Ayrıca görüşme esnasında, çalışma grubunda yer alan sekiz kişinin her soruya mutlaka cevap vermesi sağlanmıştır. Açıklık gerektiren durumlarda görüşme sırasında gerekli açıklamalar yapılmıştır. Çalışmanın dış geçerliğini sağlamak için; çalışma grubu, veri toplama arac1 ve aracın nasıl oluşturulduğu, veri toplama süreci, verilerin çözümlenmesi ve yorumlanması, bulguların nasıl düzenlendiği ayrıntılı bir biçimde tanımlanmıştır. Ayrıca görüşme yapılan öğretmen adaylarının içten ve samimi görüş bildirebilmeleri adına, araştırmacıların herhangi bir çevrim içi sınavına katılmamış olmalarına özen gösterilmiştir. 


\section{BULGULAR}

Araştırma kapsamında belirlenen ana temalar olan; geçerlik; güçlük derecesi; kaygı durumu; objektiflik; kullanışlılık; dönütlerin verilmesi; sınav ortamı; sınav öncesi çalışma süresi ana temalarına ilişkin bulgular ayrı ayrı verilmiştir. Ayrıca bulguların verilmesinde öğretmen adaylarının isimlerinin baş harfleri kullanılmıştır.

Geçerlik ana teması altında çalışma grubuna yönetilen "Çevrim içi sınavları, sınıf içi sınavlarla karşılaştırdığınızda geçerlik açısından nasıl değerlendirirsiniz?” sorusuna verilen cevaplardan bazıları şu şekildedir;

H: Sıkıntılı. Çok fazla konu yığıllyor. Sinıf içinde süre konusunda uyarı oluyor, burada olmuyor.

Se: H’ye katıllyorum. Yüz yüze eğitimde bu kadar konu birikmezdi. Çok fazla konu oluyor sinav öncesi, çalışmamız gereken çok konu oluyor. H’nin dediği gibi sınav süresini de tam kestiremiyoruz. Özetle olumlu düşünmüyorum.

S: Soru çeşitliliği yok. Hep çoktan seçmeli kullanılıyor. Bu yüzden çok iyi ölçme yapıldiğını da düşünmüyorum. Açık uçlu olsa daha iyi olur. Kendimizi daha iyi anlatabiliriz. Bilenle bilmeyeni ayırt eden bir sınav değil. Ayrıca bazı hocalar az süre verdi, bu da bizi strese soktu.

A: Çevrim içi sinavları genel olarak doğru bulmuyorum. Hocayı görememek iyi değil. Kopya da çok oluyor. Hocaların bu sınavlardan çok verim aldığını düşünmüyorum, çünkü ben pek verim alamiyorum.

I: Soru sayısı az olduğundan her bir konudan soru çıkması olası değil genel olarak çevrim içi sinavları olumsuz buluyorum. Sinıf içi sınavlar yapılmalı.

M: Bence de çevrim içi sinavlar sağllklı değil. Konu çok fazla.

N: Genel olarak ben de sağllklı bulmuyorum. Ayrıca etik de değil. Sinıf içi sinavlar şeklinde yapılsaydı bu kadar yüksek puanlar alacağımı düşünmüyorum. Kopya çok oluyor. Dokümanlar önümüzde olunca takıldı̆̆ımız sorulara bakıyoruz. Gruplaşmalar oluyor. Çalışanla çalışmayanı ayırt eden bir sinav değil.

Me: Ben de N’ye katıllyorum etik değil. Önümüzde notlar var sonuçta. Bu yüzden çalışma gereği de duymuуoruz.

Öğretmen adayları özellikle kopya olaylarının çok olmasından dolayı çevrim içi sınavların genel olarak bilenle bilmeyen öğrencileri ayırt etmede başarılı olmadığını, sürenin az olmasından dolayı kaygı yaşadıklarını, her konudan sorunun yer almamasından dolayı sınıf içi sınavların daha geçerli olduğunu düşünmektedirler.

Güçlük derecesi teması altında çalışma grubuna yönetilen "Çevrim içi sınavları, sınıf içi sınavlarla karşılaştırdığınızda güçlük açısından nasıl değerlendirirsiniz?” sorusuna verilen cevaplardan bazıları şu şekildedir; 
Se: Yardımlaşma olduğu için çevrim içi sınavlar kolay olabiliyor. Konuyu öğrenmek veya adapte olma açısından örgün daha kolay. Ama adapte olmada sıkıntı yaşandığı için ve zaman kaybı açısından da çevrim içi daha zor olabiliyor.

M: Ben birinin diğerinden zor olduğunu düşünmüyorum. Çevrim içi sınavlar genelde daha basitti. Sinıf içi sınav şeklinde de olsaydı farklı bir şey olmazdl.

I: Stnıf içi sınavlar daha zor.

H: Evet. Ayrica hocalar -ögrenciler zaten uzakta, o yüzden daha kolay sorular soralım-diye düşünüyorlar. Sinıf içi sinavlarda bazen bazı soruların Türkçesini anlamakta zorlanıyordum, çevrim içi sinavlarda öyle bir şey yaşamadım.

A: Katıllyorum. Sınıf içi sınavlar daha zordu. Soru çeşitliliği olmadı̆̆ı için ve elimizde kaynaklar olduğundan her şey daha kolay.

S: Evet, sınıf içi sinavlarda çok çeşit soru oluyor, hepsine çalışlyoruz. Çevrim içinde tek çeşit olduğu için kesinlikle daha kolay, puanlarımız tavan yaptı.

Me: Soru türüne göre ders çalışmıyoruz ki, bence hocalar yine aynı şekilde sordu. Bana kalırsa ikisi de aynı güçlükte.

N: Sinıf içi sınavlar daha zordu. Ama bana kalırsa, biz zaten dördüncü sınıf ögrencisi olduğumuz için hocalar normale göre daha fazla puan vereceklerdi.

Öğretmen adayları çevrim içi sınavların, sınav anında yardım alabilmelerinden dolayı sınıf içi sınavlara göre daha kolay olduğunu düşünmektedirler. Ayrıca çevrim içi sınavlarda soru türüne göre çeşitliliğin olmaması, sınıf içi sınavlarda ise öğretmenlerin farklı soru türlerine sınavlarında yer vermeleri, sınıf içi sınavları onlar için daha zor kılmıştır.

Kaygı durumu teması altında çalışma grubuna yönetilen "Çevrim içi sınavları, sınıf içi sınavlarla karşılaştırdığınızda yaşadığınız kaygı açısından nasıl değerlendirirsiniz?” sorusuna verilen cevaplardan bazıları şu şekildedir;

Me: Çevrim içi sınavlarda daha çok kaygı duydum. Sinavlardan önce -elektrik kesilmesine karşın dikkat edin sorumluluk sizin- gibi açıklamalar beni kaygılandırdı. Elektrik kesilirse bunu nasıl kanıtlayacă̆ım, bununla uğraşmam gerekecek. Ama sınıf içi sınavlarda böyle bir durum yok.

N: Çevrim içi sınavlarda bir sürü problem olabilir. Elektrik, internet kesintisi gibi bir sürü problem. Bunlar bizi endişelendiriyor.

A: Ben mesela internetin sıkıntılı olduğu bir yerde yaşıyorum. Bu yüzden bu kaygım ekstra daha fazla. Bir sınavda iki kere sistem beni attl, tekrar sinava girmek zorunda kaldım, bu esnada süreyi de bilmediğimden erken yolladım. Endişe verici.

M: Sınavın süresini de kestiremediğimizden çevrim içi sınavlar daha kaygıll.

I: Ben de katıllyorum. Sinavda hem telefon hem bilgisayar açık giriyorum. Bir şey olursa diğeriyle devam ederim diye. Annemle babama bir hafta boyunca beni aramayın diyorum. Sinav, beni çok 
kaygllandırır zaten daha da kaygım artıyor. Elektrik veya internet kesintisi olabilir diye odaklanmam çok zor oldu sinava.

H: Ben de katıllyorum. Bir de ben saat farkından dolayı sıkıntı yaşadım. Yunanistan saatine göre mi, yoksa Türkiye saatine göre mi girmeliyim diye.

Se: Kesinlikle katıllyorum, çevrim içi sınavlar daha kaygl verici. Sınıf içi sınavlarda sadece sınavım nasıl geçer diye düşünürken, burada bir sürü problemi düşünmek zorunda kallyoruz.

S: Bir de sınıf içi sınavlarda arkadaşlarımızla birlikte sınava girdiğimiz için sona kalsak da hocalar birkaç dakika zaman tanıyor ama burada sınav süresi bitmeden yolluyoruz bir sıkıntı çıkmasın diye.

Öğretmen adayları çevrim içi sınavların sınıf içi sınavlara göre, sınav anında yaşanabilecek elektrik veya internet kesintisi gibi kendi dışlarında olabilecek bazı problemlerden dolayı daha kaygı verici olduğunu düşünmektedirler.

Objektiflik teması altında çalışma grubuna yöneltilen "Çevrim içi sınavları, sınıf içi sınavlarla karşılaştırdığınızda objektiflik açısından nasıl değerlendirirsiniz?” sorusuna verilen cevaplardan bazıları şu şekildedir;

Su: Objektif olduğunu düşünüyorum. Ne beklediysem onu aldım.

Se: Evet çoktan seçmeli olduğu için objektif.

H: Ben katılmiyorum objektif değil bence. Hocalar sınav sonrast cevaplart verdi. Ama hesapladiğım puanı almadım.

A: Evet bazı notlarıma bakınca ben de bazı sınavlar için objektif olduğunu düşünmüyorum.

M: Ben de anlamadım. Bazılarında hocanın cevaplarına göre hesapladı̆̆ım puanı almadım. Bazılarında da çelişkili sorular vardı. Hocanın cevabı başka oluyordu kaynaklara göre mesela. Bu durum da puanlarimiza yansidl.

Me: Ben emin değilim. Bir sınavda hoca birden çok seçeneği kabul edeceğini söylemişti, ama kabul etseydi daha yüksek alırdım.

I: Bazı hocalar ödev şeklinde verdi sınavl, bu durumda objektif değil.

$N$ : Evet bence de.

Öğretmen adayları, çevrim içi sınavların tamamıyla objektif olduğu görüşünde hemfikir değillerdir. Bazı sınavlarda öğretim elemanlarının sınavın cevap anahtarını paylaştığında, buna yönelik puanlarını hesaplamalarına rağmen, farklı puanlar aldıklarını belirtmişlerdir.

Kullanışlılık teması altında çalışma grubuna yönetilen "Çevrim içi sınavları, sınıf içi sınavlarla karşılaştırdığınızda kullanışlılık açısından nasıl değerlendirirsiniz? sorusuna verilen cevaplardan bazıları şu şekildedir;

I: Çok ekonomik. Bir sayfaya gir tıkla. Zaman açısından da sınıf içi sınavlara göre kullanışlı.

Se: I'ye katıllyorum. Sınıf içi sınavlarda illa ki okula gitmemiz gerekiyor. 
N: Evet katıllyorum. Özellikle benim için kullanışlılık açısından çevrim içi sınavlar çok iyi. Çalıştı̆̆ım için zaman ve mekân önemli değil. Bu olumlu bir yanı.

Me: Kullanışlı evet. Her şeyden tasarruf ediyorsunuz.

M: KPSS de olduğu için bize zaman kazandırtyor.

A: Evet doğru.

S: Okul için de kullanışlı aslında. Kâğıt ve fotokopi tasarrufu. Not çıkarma açısından da sınıf içi sınavlara göre daha az not çıkardı̆̆ımız için daha kullanışlı.

H: Evet kullanışlı. Olduğumuz yerden sınava girebildiğimiz için kısa sürüyor.

Öğretmen adayları çevrim içi sınavların zamandan ve mekândan bağımsız olmasından, kâğıt ve fotokopi gerektirmediğinden ve kısa sürmesinden dolayı sınıf içi sınavlara göre daha kullanışlı olduğunu belirtmişlerdir.

Dönütlerin verilmesi teması altında çalışma grubuna yöneltilen "Çevrim içi sınavları sınıf içi sınavlarla karşılaştırdığınızda notların duyurulması ve verilen dönütler açısından nasıl değerlendirirsiniz?” sorusuna verilen cevaplardan bazıları şu şekildedir;

M: Sinıf içi sınavlara göre daha çabuk ögrendik notlarımızı daha iyi.

Me: Ben öyle düşünmüyorum. Hemen dönüt verilmedi ki. Tek bir sınavda öyle oldu ama sınıf içi sinavlarla ayn diyebilirim.

I: Me’ye katıllyorum. Hocalar çok geç girdi notları sisteme. Sistem direk sonuçları veriyor ama onlar abs sistemine geç girdi.

Se: Çevrim içinde sorular aklımızda daha çok kaldı̆̆ için sınıf içi sınavlara göre soruların cevaplarını almak daha hızlı ve faydalı. Notlar da daha erken açılandı.

A: Bence ikisi de aynı sürede açıklandı. Çevrim içinde daha erken açıklanabilirdi ama geç açıklandl.

N: Bence de sonuçlara ulaşma açısından aynı ikisi de.

S: Çevrim içinde soruların hepsi çoktan seçmeli olduğu için hemen açıklanır diye düşünmüsstüm ama geç açıklandl.

H: Evet notların açıklanması geç oldu.

Öğretmen adayları, çevrim içi sınavlarda değerlendirmenin sistem tarafından hızlı bir şekilde yapılmasından dolayı, sınav sonrası notlarının hemen açıklanmasını beklerken, sınıf içi sınavlardan farklı bir sürede açıklanmadığını, beklediklerinden daha geç sürede açıklandığını belirtmişlerdir. Bu süreçte öğretim elemanlarının üniversite sistemine notları geç girdiklerini düşünmektedirler.

Sınav ortamı teması altında çalışma grubuna yönetilen "Çevrim içi sınavları, sınıf içi sınavlarla karşılaştırdığınızda sınav ortamı açısından nasıl değerlendirirsiniz?” sorusuna verilen cevaplardan bazıları şu şekildedir; 
N: Öncelikle ahlaki ilkelerinizi rafa kaldırıyorsunuz. Çünkü onlar sınav ortamında çok işinize yaramayacak. Her ne kadar dürüst olacağım deseniz de bu mümkün değil. Önümüzde dokümanlar var, o yüzden sorunun cevabını bilmediğinizde bakıyorsunuz ister istemez. Etik bulmuyorum ama sistem sizi ona mahkûm ediyorsa yapıyorsunuz.

Me: N'ye kattliyorum.

M: Katıllyorum. Sinıf içi sınavlara göre çevresel koşullar açısından daha rahatız ama uygun değil.

H: Evet rahatız. Zorlanınca notlara baklyoruz.

S: Evet rahatız. Sınıf içi sınavlarda hoca başında, sınıf ortamındasın. Bunda eğer evdekiler ses yapmiyorsa, her şey çok rahat. Kendi kendime ders çalışlyormuş gibi hissettim.

A: Evet rahatız. Gözetmen yok, istediğimizde açıp bakıyoruz.

I: Evet rahatız. Sınıf içi sınavlarda sınıf içinde en ufak bir sesten etkileniyoruz. Gözetmenler dolaşınca rahatsız oluyoruz.

Se: Aslında kâğıtları açıp bakmayı rahatlık olarak adlandırmak, açıkçası beni rahatsız ediyor. Sinıf içi sinavlarda da kopya çekemeyen biriyim. Çevrim içi sinavlarda da yapmamaya çok direndim ama sonunda... Bu doğru bir durum olmadı̆̆ için bunu rahatlık olarak adlandırmak istemiyorum. Vicdanen rahat değilim. Bir de sinıf içi sinavlarda herkesle birlikte sinava girmek, beni daha fazla motive ediyordu. Çevrim içi sınavlarda ekrandan açıp bakmak bana öylesine bir şey yapıyormuşum hissi veriyor. Ev ortamında da müsait değilim. Yaşlımız var, çok ses yapıyor. O yüzden, sinıf içi sinavlar benim için daha rahat.

Öğretmen adayları çevrim içi sınavların ortamını, cevabını bilemedikleri bir soruda ders notlarına ya da kaynaklarına kolaylıkla bakabilmelerinden, sınıf ortamındaki dikkatlerini dağıtan durumların (gözetmen, gürültü gibi) olmamasından dolayı sınıf içi sınavlara göre daha rahat bulmuşlardır. Sadece bir kişi sınav anında ellerindeki kaynaklara bakabilmeyi rahatlık olarak adlandırmak istememiş ve bu durumdan vicdanen rahatsız olduğunu belirtmiştir.

Sınav öncesi çalışma süresi teması altında çalışma grubuna yönetilen "Çevrim içi sınavları, sınıf içi sınavlarla karşılaştırdığınızda sınav öncesi ders çalışma süresi açısından nasıl değerlendirirsiniz?" sorusuna verilen cevaplardan bazıları şu şekildedir;

Me: Dersten derse değişiyor. Ama sınıf içi sınavlar şeklinde olsaydı hepsine çalışırdım. Şimdi en fazla 1,5 saat çalışmışımdır.

A: Me ile aynı görüşteyim. Bazı derslere nasılsa kaynaklar önümde olacak diye hiç çalışmadım. Ama sını içi sınavlarda 1-2 hafta öncesinden başlıyoruz çalışmaya.

H: A'ya katıllyorum.

N: Evet ben de çok çalışmadım. Nasılsa benim bilmediğimi arkadaşım biliyordur diye düşündüm.

M: Benim için değişmedi. Sınıf içi sınavlarda da son akşam çalışırdım. 
Se: Evet M'ye katıllyorum. Hiçbir zaman sınavdan 2-3 hafta önce ders çalı̧̧maya başlayan bir ögrenci olmadım. Bu durum çevrim içi sınavlarda da değişmedi.

I: Ben de Mve Se'ye katıllyorum ama biraz daha farklı olarak. Ben sinıf içi sınavlarda 2-3 hafta öncesinde başlardım çalışmaya; notlarımı çıkarır, sınavın olduğu gün de notları tekrar ederdim. Çevrim içi sınavlarda da aynısını yaptım. Çünkü en önce kendi bilgime güvenirim.

S: Sınıf içi sınavlarda çok not çıkarıyordum. Burada hiç olmadı. Slaytları okuyup kısa kısa not aldım. Çevrim içi sınavlarda çok yorulmadım.

Öğretmen adayları genel olarak sınav öncesinde ders çalışmaya ayırdıkları zaman açısından çevrim içi sınavlar için daha az sürede ders çalıştıklarını belirtmişlerdir. Birkaç öğrenci ise hem sınıf içi sınavlar hem de çevrim içi sınavlar için sınav öncesi ders çalışmaya ayırdıkları sürenin benzer olduğunu belirtmiştir.

\section{SONUÇ ve TARTIŞMA}

Öğretmen adaylarının görüşlerine göre, sınıf içi sınavlar, çevrimiçi sınavlara göre daha geçerlidir. $\mathrm{Bu}$ görüşlerine gerekçe olarak çevrimiçi sınavlarda kopya olaylarının çok yaşanmasını, sınav süresi ve buna bağlı olarak artan kaygılarını belirtmişlerdir. Burada öne çıkan ilk konu akademik sahtekârlık olarak nitelendirilebilen kopya çekme olaylarının artışıdır. Uzaktan eğitimde yapılan ölçme ve değerlendirme çalışmalarında eğer sistemsel ya da kurumsal bir önlem alınmamışsa sınavlar genellikle gözetimsiz olarak gerçekleştirilmektedir. Sınavların gözetimsiz ve önlemsiz yapılması sınavlarda kopya çekme olaylarının artmasına neden olmuştur. Uluslararası Akademik Dürüstlük Merkezi’nin [ICAI] (2020) yapmış olduğu araştırmada lisans öğrencilerinin \%32'si sınavlarda kopya çektiklerini; öğrencilerin \%60'ından fazlasının bir şekilde kopya çekmeyi özgürce kabul ettiğini göstermiştir. King ve Case ( 2014) öğrencilerin \%74'ünün (yaklaşık 4'te 3'ü) çevrimiçi bir sınavda kopya çekmenin ya çok kolay ya da biraz kolay olduğuna inandıklarını ortaya koymuştur. Öğrencilere çevrimiçi ve yüz yüze sınıflarda akademik olarak dürüst olmayan davranışlarda bulunma olasılıklarının sorulduğu araştırmada sonuçlar çevrimiçi kurslarda (\%42) yüz yüze kurslara (\%10) göre neredeyse dört kat daha fazla kopya çekme olasıllı̆ının olduğunu göstermiştir (Watson ve Sottile 2010). Benzer şekilde Ebaid (2021) çalışmasında çevrimiçi sınavların öğrencilere yüz yüze yapılan sınavlara kıyasla kopya çekme konusunda daha fazla şans verdiğini ortaya koymuştur.

Sınıf içi sınavlara kıyasla çevrimiçi sınavlarda sürenin yeterli olmaması öğrencilerin kaygılarını arttıran olumsuz bir durum olarak görülmüştür. Özellikle yorum gerektiren ve üzerine düşünülmesi gereken sorularda sürenin yeteri kadar verilmemesi öğrencilerde paniğe neden olmaktadır. Almossa'nın (2021) yapmış olduğu araştırmada da sınav süresinin yetersizliği ve buna bağlı olarak ortaya çıkan yüksek kaygı, öğrencilerin en çok eleştirdikleri sorun olmuştur. Süreyle bağlantılı olan bir başka sorun ise sınav anında yaşanan teknik sorunlardır. Öğrencilerin aynı anda sisteme girmesi, sistemden kaynaklı olarak sınavdan kopmalara neden olmakta ve bu durum, öğrencilerin sınavdan çok başka sorunlarla 
uğraşmalarına neden olmaktadır. Alanyazında Suudi Arabistan'daki üniversite öğrencilerinin KOVID19 pandemisinde çevrimiçi öğrenme ve değerlendirmeye yönelik "tweetlerinde" olumsuz "hashtagli tweetlerin" \% 70'i teknik sorunlarla ilgili olmuştur. Uzaktan eğitimde yaşanan bağlantı ve teknolojik altyapıyla ilgili sorunlar birçok araştırmanın (Almossa, 2021; Dolmacı ve Dolmacı, 2020; İmamoğlu ve İmamoğlu,2020; Keskin ve Özer, 2020) bulgusunda göze çarpmaktadır.

Sınav zorluğu açısından çevrimiçi sınavlar, sınıf içi sınavlardan daha kolay görülmüştür. Bunun gerekçesi olarak sınav anında kitaplara bakabilmelerini, soru çeşitliliğinin olmamasını ve yardım alabilmelerini göstermişlerdir. Khan ve Balasubramanian (2012) öğrencilerin teknoloji ile birlikte elektronik kaynaklara hızlı ulaşabilmelerinin, çevrimiçi ortamlarda kopya çekmeye ilişkin tutumlarını olumlu yönde arttırdığını vurgulamaktadır. Bu araştırmacılar, öğrencilerin \%37.5'inin (sınavlar sırasında arkadaşlar arasında) sınıf içi kopya çekmeyi kabul ettiğini, \%78'inin ise teknoloji veya e-kopyalamayı kullanarak kopya çekmeyi kabul ettiğini ortaya koymuşlardır.

Sonuç itibariyle, çevrim içi öğrenme ortamına ve bu doğrultuda çevrim içi sınav sistemine zorunlu ve beklenmedik bir durumda geçilen bu süreçte, yaşanılan problemlerin en önemlisi sınav güvenliğidir. Çevrim içi sınavlar her ne kadar zamandan ve mekândan bağımsız olarak yapılabilse de, bu sınavların geçerlik ve güvenirliği tartışılmaktadır. Öğrencilerin öğrenim gördükleri alandan mezun olduklarında elde ettikleri not ortalamaları onların bu alanda ne kadar okuryazar olduklarının da bir göstergesidir. $\mathrm{Bu}$ durumda elde etmiş oldukları bu notların ölçülmesi sürecinde kullanılan ölçme araçlarından, sınavın yapılma şekline kadar her bir aşama büyük bir öneme sahiptir. Sınav sonuçlarının geçerli ve güvenilir olması aslında o öğrencilerin alanları ile ilgili ne kadar donanımlı olduklarına işaret etmektedir. Tabi ki bir sınavın geçerli ve güvenilir olması için tek çözüm, mutlaka sınıf içi ortamda yapılması değildir. Sınıf içi sınavlarda da sınavın hazırlanmasından uygulanmasına kadar hataya sebebiyet verebilecek tüm durumların önüne geçilmesi gerekir. Özetle, sınavlar çevrim içi veya sınıf içi ortamda hatalardan arınık bir şekilde yapılabildiği takdirde, elde edilen sonuçların bir anlam teşkil ettiği söylenebilir.

\section{KAYNAKÇA}

Almossa, S.Y.(2021) University students' perspectives toward learning and assessment during COVID19. Education and Information Technology. 1-19, 10.1007/s10639-021-10554-8.

Al-Shalout, M. I., Rasmi, M., \& Hassan, M. A. (2021). Evaluation of E-exam during Covid-19. Psychology and Education Journal, 58(1), 4604-4612.

Atılgan, vd. (2021). Tıp fakültesi öğrencilerinin gözünden acil uzaktan öğretim sürecinin değerlendirilmesi. Sürekli Tip Ĕgitimi Dergisi, 29(6), 396-406. 10.17942/sted.837551.

Daniels, L.M., Goegan, L.D. \& Parker, P.C. (2021).The impact of COVID-19 triggered changes to instruction and assessment on university students' self-reported motivation, engagement and perceptions. Soc Psychol Educ 24, 299-318. https://doi.org/10.1007/s11218-021-09612-3 
Dolmacı, M. ve Dolmac1, A. (2020). Eş zamanlı uzaktan eğitimle yabanc1 dil öğretiminde öğretim elemanlarının görüşleri: Bir Covid 19 Örneği. Türk Eğitim Bilimleri Dergisi, 18(2), 202-228.

Ebaid, I. E. S. (2021). Cheating among Accounting Students in Online Exams during Covid-19 Pandemic: Exploratory Evidence from Saudi Arabia. Asian Journal of Economics, Finance and Management, 919.

Hodges, C., Moore, S., Lockee, B., Trust, T., \& Bond, A. (2020). The difference between emergency remote teaching and online learning. Educause Review, 27, 112. https://medicine.hofstra.edu/pdf/faculty/facdev/facdev-article.pdf

İmamoğlu, H. V., ve İmamoğlu, F. S. (2020). Coronavirüs Salgını ve Uzaktan Eğitim Süreci Hakkında Öğretmen Görüşleri: Şehit Bülent Yalçın Spor Lisesi ve Şehit Ertan Yılmaz Güzel Sanatlar Lisesi (Sinop) Örneği. Journal of Humanities and Tourism Research, 10(4), 742-761.

Karahocagil MK, Çiçek M, Güneş A. (2021). Küresel salgının tıp eğitimi üzerine etkileri ve uzaktan eğitim tecrübesi. Tlp Eğitimi Dünyası, 20(60-1), 87-90.

Keskin, M., ve Özer, D. (2020). COVID-19 sürecinde öğrencilerin web tabanlı uzaktan eğitime yönelik geri bildirimlerinin değerlendirilmesi. İzmir Katip Çelebi Üniversitesi Sağllk Bilimleri Fakültesi Dergisi, 5(2), 59-67.

Khan, Z. R., \& Balasubramanian, S. (2012). Students go click, flick and cheat... e-cheating, technologies and more. Journal of Academic and Business Ethics, 6, 1-26.

King, D. L., \& Case, C. J. (2014). E-cheating: incidence and trends among college students. Issues in Information Systems, 15(1), 20-27.

Özer-Özkan, Y. ve Turan, S. (2021). Düşündürdükleri ve ötesiyle yüksek riskli sınav gerçeği. AlanyazınCRES Journal 2(2), 59-63. http:/dx.doi.org/10.22596/cresjournal.0201.59.63

Rossiter, S. (2020). Cheating becoming an unexpected COVID-19 side effect for universities. https://www.cbc.ca/news/canada/edmonton/cheating-becoming-an-unexpected-covid-19-side-effectfor-universities-1.5620442

Sarı, H. İ. (2020). Evde kal döneminde uzaktan eğitim: Ölçme ve değerlendirmeyi neden karantinaya almamalıyız? Uluslararası Eğitim Araştırmacıları Dergisi, 3(1), 121-128.

Uluslararası Akademik Dürüstlük Merkezi'nin [ICAI] (2020) https://academicintegrity.org/resources/factsand-statistics. Erişim tarihi: 01.06.2021.

Watson, G., \& Sottile, J. (2010). Cheating in the digital age: Do students cheat more in online courses? Online Journal of Distance Learning Administration, 13(1). n. pag. Web. http://www.westga.edu/ distance/ojdla/spring131/watson131.html.

Yıldırım, A. ve Şimşek, H. (2005). Sosyal Bilimlerde Nitel Araştırma Yöntemleri Güncelleştirilmiş Geliştirilmiş 5. Baskı, Ankara: Seçkin Yayıncılık. 